\title{
Research Aвтіск: Effect of inoculation with VAM fungi at different $P$ levels on flower yield, petal meal yield, mycorrhizal spore count in the root- zone soil and percentage root colonization (PRC) of Tagetes erecta $\mathrm{L}$.
}

\author{
G. SWATHI AND B. HEMLA NAIK
}

Article Chronicle: Received : 11.07.2017; Accepted : 26.07.2017

KEY WoRds: Marigold, VAM, Phosphorus, Glomus fasciculatum, G. mosseae, G. Intraradices, Yield, Petal meal, Mycorrhiza, Spore count

Author for correspondence :

SUMMARY : In this experiment the VAM fungi viz., Glomus fasciculatum (Thaxter) Gerd. and Trappe, Glomus mossea (Nicol. and Gerd.) Gerd. and Trappe, Glomus intraradices Schenck and Smith. with an un-inoculated control was maintained and three P levels viz., 60, 90, $120 \mathrm{~kg} \mathrm{ha}^{-1}$ were tried. The results brought out that the plants inoculated with G. fasciculatum and given $\mathrm{P}$ at $90 \mathrm{~kg} /$ ha recorded significantly highest number of flowers per plant (117.80) and least was observed in uninoculated control plants with given $P$ at $60 \mathrm{~kg} / \mathrm{ha}(80.53)$. Similarly, the plants inoculated with $G$. fasciculatum and given $P$ at 90 $\mathrm{kg} /$ ha recorded significantly maximum flower yield $(626.73 \mathrm{~g} /$ plant, $17.83 \mathrm{t} / \mathrm{ha})$ and it was statistically on par with G. mosseae (618.73 g/ plant, $17.73 \mathrm{t} / \mathrm{ha}$ ) at the same level of $\mathrm{P}$ and least was observed in uninoculated control plants with given $P$ at $60 \mathrm{~kg} / \mathrm{ha}(446.73 \mathrm{~g} / \mathrm{plant}, 11.61 \mathrm{t} / \mathrm{ha})$. Petal meal yield per kilogram of fresh flower $(87.83 \mathrm{~g})$, petal meal yield per hectare $(15.66 \mathrm{q})$, were significantly higher with the inoculation of G.fasciculatum and given P at $90 \mathrm{~kg} /$ ha followed by G. mosseae (83.83g and $14.85 \mathrm{q}$, respectively) at the same level of $\mathrm{P}$ than the other species of Glomus fungi and uninoculated control. The plants inoculated with G. fasciculatum and given $\mathrm{P}$ at $90 \mathrm{~kg} /$ ha recorded significantly highest spore count (279.67 and 407.67, respectively) and highest PRC (85.33 and 93.67, respectively) which was found to be superior as compared to other species of Glomus fungi.

How to cite this article : Swathi, G. and Naik, B. Hemla (2017).Effect of inoculation with VAM fungi at different $\mathrm{P}$ levels on flower yield, petal meal yield, mycorrhizal spore count in the root- zone soil and percentage root colonization (PRC) of Tagetes erecta L. Agric. Update, 12 (TECHSEAR-4): 903-911; DOI: 10.15740/HAS/AU/

\section{G. SWATHI}

Department of Floriculture and Landscape

Architecture, College of Horticulture, Mudigere, CHIKMAGALUR (KARNATAKA) INDIA Email: kiraswathi@ gmail.com

See end of the article for authors' affiliations 